\title{
Infectious hematopoietic necrosis virus: monophyletic origin of European isolates from North American Genogroup M
}

\author{
P.-J. Enzmann ${ }^{1, *}$, G. Kurath ${ }^{2}$, D. Fichtner ${ }^{3}$, S. M. Bergmann ${ }^{3}$ \\ ${ }^{1}$ Friedrich-Loeffler-Institut, Federal Research Institute for Animal Health, Paul-Ehrlich-Straße 28, 72076 Tübingen, Germany \\ ${ }^{2}$ Western Fisheries Research Center, Biological Resources Division, US Geological Survey, 6505 NE 65th Street, Seattle, \\ Washington 98115, USA \\ ${ }^{3}$ Friedrich-Loeffler-Institut, Federal Research Institute for Animal Health, Boddenblick 5a, 17493 Insel Riems, Germany
}

\begin{abstract}
Infectious hematopoietic necrosis virus (IHNV) was first detected in Europe in 1987 in France and Italy, and later, in 1992, in Germany. The source of the virus and the route of introduction are unknown. The present study investigates the molecular epidemiology of IHNV outbreaks in Germany since its first introduction. The complete nucleotide sequences of the glycoprotein (G) and nonvirion (NV) genes from 9 IHNV isolates from Germany have been determined, and this has allowed the identification of characteristic differences between these isolates. Phylogenetic analysis of partial G gene sequences (mid-G, 303 nucleotides) from North American IHNV isolates (Kurath et al. 2003) has revealed 3 major genogroups, designated $U, M$ and L. Using this gene region with 2 different North American IHNV data sets, it was possible to group the European IHNV strains within the M genogroup, but not in any previously defined subgroup. Analysis of the full length G gene sequences indicated that an independent evolution of IHN viruses had occurred in Europe. IHN viruses in Europe seem to be of a monophyletic origin, again most closely related to North American isolates in the M genogroup. Analysis of the NV gene sequences also showed the European isolates to be monophyletic, but resolution of the 3 genogroups was poor with this gene region. As a result of comparative sequence analyses, several different genotypes have been identified circulating in Europe.
\end{abstract}

KEY WORDS: Infectious hematopoietic necrosis virus · European strains · Molecular epidemiology · IHNV groups

\section{INTRODUCTION}

Infectious hematopoietic necrosis virus (IHNV), the causative agent of infectious hematopoietic necrosis, belongs to the rhabdovirus genus Novirhabdovirus (Morzunov et al. 1995, Pringle 1999, Enzmann 2000).

IHNV was originally observed as a disease of mainly Pacific salmon and trout in enzootic areas in western North America. In 1987, IHNV was detected in France and Italy (Baudin-Laurencin 1987, Bovo et al. 1987). In 1992, IHNV was isolated for the first time from rainbow trout Oncorhynchus mykiss in Germany (Enzmann et al. 1992). Since then a series of IHN outbreaks have occurred in various parts of Germany and the final diagnosis of virus isolates from infected fish was made in the Friedrich-Loeffler-Institut, Tübigen (P.-J. Enzmann unpubl.). The first introduction of IHNV as well as several further infections in German rainbow trout farms could be attributed to various fish importsmostly from Italy, but later also from France. Since there are rigid EU regulations regarding fish transport in Europe, the source of rainbow trout in a farm can easily be determined from the accompanying health certificate.

Previous studies of IHNV evolution have described the extent of molecular evolution within North America (Nichol et al. 1995). In a recent study based on 323 IHNV field isolates in North America, sequence analy- 
sis of a 303 nucleotide variable region (mid-G) within the glycoprotein gene $(G)$ revealed 3 major virus genogroups, designated $\mathrm{U}, \mathrm{M}$ and $\mathrm{L}$, indicating their general correlation with the upper, middle and lower portions of the geographical distribution of IHNV in North America (Kurath et al. 2003). In subsequent work, an extensive regional study of IHNV in the Columbia River basin revealed it to be a focus of both $\mathrm{U}$ and $\mathrm{M}$ genogroup IHNV (Garver et al. 2003). The current study details the identification and molecular characterisations of IHNV strains detected in Germany, and also includes representative strains from Europe and North America. The phylogenetic relationship of the IHNV isolates in Germany to those previously reported is analysed.

\section{MATERIALS AND METHODS}

Cells and virus strains. The EPC (epithelioma papulosum cyprini) cell line was used for propagation of viral strains. IHNV reference strains RB, WRAC, and SRCV were obtained from the Marine Science Centre, Newport, Oregon, USA. Strain IHNcod was obtained from Theodore Meyers, Department of Fish and Game, Juneau, Alaska. Strain IHNFryer (Fryer et al. 1976) is a partially attenuated strain obtained from the Department of Microbiology, Oregon State University, Corvallis, Oregon, USA. European isolates are denoted with the prefix 'IE' for IHNV-European, followed by the isolate name. The history of IHNV Strain IE.332, the first isolate in Germany, has been described earlier (Enzmann et al. 1992). Strains IE.62, IE.42, IE.D30, IE.13, IE.8, and IE.Vi100 were obtained from different Fish Health Services in Germany. The history of Strain IE.8 (original identification DF04-99) has been described recently (Fichtner et al. 2000). All virus strains were cloned using the end points of at least 4 titrations in cell culture.

RT-PCR. RNA isolation and RT-PCR were performed as described by Miller et al. (1998). Briefly, viral RNA was isolated from $1 \mathrm{ml}$ cell culture supernatant using an RNeasy total RNA kit (Qiagen). Reverse transcription of heat-denatured RNA $\left(2 \min 92^{\circ} \mathrm{C}, 2 \min 4{ }^{\circ} \mathrm{C}\right.$ in the presence of 10 pmol sense primer IG1) was performed in a $25 \mu$ reaction after addition of $5 \mu \mathrm{l}$ RT buffer (Promega) (125 mM Tris- $\mathrm{HCl} \mathrm{pH} \mathrm{8.3;} 187.5 \mathrm{mM}$ $\mathrm{KCl}_{;} 7.5 \mathrm{mM} \mathrm{MgCl}_{2} ; 25 \mathrm{mM}$ dithiothreitol; $0.25 \mathrm{mM}$ of each dNTP); 8 U of RNase inhibitor (RNasin, Promega), and $50 \mathrm{U}$ of reverse transcriptase (Promega) for $1 \mathrm{~h}$ at $42^{\circ} \mathrm{C}$. Following reverse transcription, $5 \mu \mathrm{l}$ of cDNA was added to the PCR mixture containing $10 \mathrm{pmol}$ sense (IG1) and antisense primer (INV2), $0.25 \mathrm{mM}$ of each dNTP, $10 \mathrm{mM}$ Tris- $\mathrm{HCl} \mathrm{pH} 9.0 ; 50 \mathrm{mM} \mathrm{KCl}_{\text {; }}$ $2.5 \mathrm{mM} \mathrm{MgCl} 2,0.1 \%$ Triton X-100, 1.5 U Taq DNA
Table 1. Primers used for RT-PCR and sequencing of IHNV isolates in present study

\begin{tabular}{|ll|}
\hline Primer & \multicolumn{1}{c|}{ Sequence } \\
\hline IG1 & 5'-ATGGACACCATGATCACC-3' \\
IGR & 5'-CCGGTTTGCCAGGTGATACAT-3' \\
ID4 & 5'-CTCTGGACAAGCTCTCCAAGG-3' \\
ID3 & 5'-GATTGGAGATTTTATCAACA-3' \\
INV1 & 5'-TGTATCACCTGGCAAACCGG-3' \\
INV2 & 5'-CAAGATCGAAGAAGTCCAT-3' \\
\hline
\end{tabular}

Polymerase (Qiagen), and water up to a final volume of $100 \mu \mathrm{l}$. Amplification conditions were 35 cycles of denaturation at $95^{\circ} \mathrm{C}$ for $30 \mathrm{~s}$, annealing at $52^{\circ} \mathrm{C}$ for $40 \mathrm{~s}$, and extension at $72^{\circ} \mathrm{C}$ for $40 \mathrm{~s}$. The primers IG1 and INV2 were used for the amplification of complete $\mathrm{G}$ and NV genes, including intergenic sequences. The resulting PCR products spanned from Nucleotides 3007 to 5043, i.e. $2037 \mathrm{nt}$, in respect to the complete genome sequence in GenBank Accession No. X89213 (Schütze et al. 1995). Table 1 lists the primers used for PCR and sequencing.

Sequence and phylogenetic analysis. The DNA obtained after RT-PCR was separated by $1.3 \%$ agarose gel electrophoresis and purified using a QIAquick gelextraction kit (Qiagen). Sequences were obtained with the fluorescent dye deoxy-terminator cycle sequencing kit (Perkin Elmer). The products of the sequencing reaction were purified by ethanol precipitation and analysed by an ABI Prism 377 DNA sequencer (Applied Biosystems). All sequences were confirmed by sequencing both strands.

Nucleotide sequences of the G and NV gene open reading frames (ORFs) of IHNV strains were analysed separately. Note that the first $18 \mathrm{nt}$ of the G gene ORF were determined by the sequence of Primer IG1, which started at the first ATG start codon.

Phylogenetic analyses were carried out with the neighbour-joining and parsimony programs in PAUP, as described in detail earlier (Kurath et al. 2003). In all cases the topography of parsimony trees agreed with that of the analogous neighbour-joining trees, but with lower bootstrap values at some nodes.

Phylogenetic trees were constructed for the mid-G region of the glycoprotein genes (Kurath et al. 2003) and for the entire ORFs of the G genes and NV genes. Genome regions used for phylogenetic studies were G gene: mid-G: Nucleotides 3646 to 3948 (303 nt); complete G gene ORF: nucleotides 3007 to 4533 (1527 nt, from start codon to stop codon); NV gene ORF: nucleotides 4604 to 4939 (336 nt, from start codon to stop codon). Table 2 gives accession numbers of the $\mathrm{G}$ gene nucleotide sequences from the European strains. 
Table 2. Virus isolates sequenced in this study, with accession nos. $(G=$ glycoprotein; $N V=$ non-virion; ORF: open reading frame) and year of isolation. " Strains used as reference viruses; ${ }^{* *}$ complete genome sequence, Accession No. X89213 (all isolates from rainbow trout, except 13 [from eel] and IHNcod [from cod]); S: Southern Germany; N: Northern Germany; L: laboratory strain; -: IHNV isolates from North America sequenced for comparison

\begin{tabular}{|c|c|c|c|c|c|c|}
\hline $\begin{array}{l}\text { Virus } \\
\text { isolate }\end{array}$ & $\begin{array}{l}\text { G ORF } \\
\text { Accession }\end{array}$ & $\begin{array}{l}\text { NV ORF } \\
\text { Accession }\end{array}$ & $\begin{array}{c}\text { Year of } \\
\text { isolation }\end{array}$ & Notes & & Source \\
\hline 332 & AY331657 & AY780890 & 1992 & $\begin{array}{l}\text { First outbreak in Germany, } \\
\text { rainbow trout from Italy }\end{array}$ & $\mathrm{S}$ & Enzmann et al. (1992) \\
\hline 13 & AY331658 & AY780891 & 1998 & Isolate from wild elver & $\mathrm{N}$ & Bergmann et al. (2003) \\
\hline 28 & AY331659 & AY780892 & 2002 & Highly pathogenic & $\mathrm{N}$ & Bergmann et al. (2003) \\
\hline 8 & AY331660 & AY780893 & 1999 & Limited reaction with common mab & $\mathrm{N}$ & Fichtner et al. (2000) \\
\hline 832 & AY331661 & AY780894 & 1994 & Highly pathogenic & $\mathrm{S}$ & Enzmann unpubl. \\
\hline D30 & AY331662 & AY780895 & 1995 & Series of outbreaks in Black Forest & $\mathrm{S}$ & Enzmann unpubl. \\
\hline 42 & AY331663 & AY780896 & 1995 & & $\mathrm{~S}$ & Enzmann unpubl. \\
\hline 62 & AY331664 & AY780897 & 1995 & & $\mathrm{~S}$ & Enzmann unpubl. \\
\hline $1 \mathrm{~F}$ & X89213 & X89213 & 1987 & First French outbreak & $\mathrm{L}$ & Schütze et al. (1995) ${ }^{* *}$ \\
\hline Vi100 & AY331666 & AY780898 & 1996 & In rainbow trout imported from France & $\mathrm{S}$ & Enzmann unpubl. \\
\hline $\mathrm{RB}^{*}$ & Reference & & 1976 & Obtained from Marine Science Centre, & - & Koener et al. (1987) \\
\hline WRAC ${ }^{*}$ & isolate se- & & 1982 & Newport, Oregon & - & Nichol et al. (1995) \\
\hline $\mathrm{SRCV}^{*}$ & quence not & & 1966 & & - & Nichol et al. (1995) \\
\hline IHNFryer* ${ }^{*}$ & delivered & & 1976 & Attenuated strain & - & Fryer et al. (1976) \\
\hline $\mathrm{IHNcod}^{*}$ & to GenBank & & 1993 & $\begin{array}{l}\text { Department of Fish and Game, } \\
\text { Juneau, Alaska }\end{array}$ & - & Enzmann unpubl. \\
\hline
\end{tabular}

\section{RESULTS}

\section{Virus isolates sequenced}

To investigate the genetic variability of IHNVs in Germany, we determined the nucleotide sequence of the $\mathrm{G}$ and $\mathrm{NV}$ gene open reading frames (ORFs) from 10 European isolates (1987 to 2002) and analysed their phylogenetic relationship to several North American reference viruses. Of the 10 isolates, 9 were from different regions of Germany. Table 2 shows a list of viral isolates sequenced in present study.

Of these virus isolates, 2 (IE.Vi100 and IE.332) most likely represent French and Italian strains, respectively, since they were isolated from infected rainbow trout that had been imported from these countries to Germany. Strain IE.1F represents the first IHNV isolate from France. This virus was used as a laboratory reference strain and the nucleotide sequence of the complete genome has been reported by Schütze et al. (1995). The isolates used in this study were from different regions of Germany, i.e. they represent the most important outbreaks of IHNV in the time period from 1992 to 2002. During this time, 96 outbreaks occurred in rainbow trout culture.

Only virus strains highlighted by special features were included into this study: 2 isolates (IE.28 and IE.832) were highly pathogenic, i.e. causing high mortality in rainbow trout aquaculture, and 1 strain (IE.8) had a reduced reactivity against monoclonal antibodies commonly used for diagnosis (Fichtner et al. 2000).
Isolates from 3 outbreaks (IE.D30, IE.42 and IE.62), were chosen because of no known interrelation between the 3 neighbouring farms (without common water supply) in which the outbreaks occurred. The only isolate not derived from rainbow trout (Isolate IE.13) was selected because it was obtained from wild elver Anguilla anguilla, which is a new host for IHNV (Bergmann et al. 2003).

For each of these isolates a contiguous region of 2063 nt was determined, beginning with the start of the $\mathrm{G}$ gene ORF and continuing through to the end of the NV gene ORF. The European isolates varied from each other in the G gene ORF by 0 to $2.3 \%$ ( 0 to $35 \mathrm{nt}$ exchanges), and 2 isolates (42 and 62) were identical in this region. The European isolates varied from each other in the NVgene ORF by 0 to $2.1 \%$ ( 0 to 7 nt exchanges); 2 isolates (IE.1F and IE.832) were identical in this region.

The North American reference strains RB1, WRAC, SRCV, IHNFryer and IHNcod were sequenced in addition. Only minimal differences from those sequences already available were obtained, although these viruses (WRAC and SRCV [Nichol et al. 1995] and RB1 [Koener et al. 1987]) were passaged for at least 8 times in our laboratory in Tübingen.

\section{Phylogenetic analysis of mid-G region of European isolates in context of North American genogroups}

A $303 \mathrm{nt}$ partial region (mid-G) of the IHNV-G gene was used to characterise the 10 European (mostly German) IHNV strains in the context of the known North 
American genogroups. The mid-G region was selected by Kurath et al. (2003) to group 323 North American IHN virus isolates into 93 sequence types, which subsequently fell into the 3 major genogroups $\mathrm{U}, \mathrm{M}$ and $\mathrm{L}$ in phylogenetic analyses.

Mid-G sequence types determined here are denoted with the prefix 'Img' for IHNV mid-G, followed by the isolate name(s). In this mid-G region, 2 of the German isolates, IE.42 and IE.62, were identi$\mathrm{cal}$, so they defined a single sequence type designated Img.4262. The other mid-G sequences from the European isolates were each unique, so a total of 9 European mid-G sequence types are defined in this work. None of these sequence types were identical to any of the known North American mid-G sequence types. The European mid-G sequences were included in a phylogenetic analysis with the 93 North American sequence types defined by Kurath et al. (2003). The resulting tree (Fig. 1) revealed that all the European strains belong to the $M$ genogroup of IHNV, but they are not within any of the previously defined Subgroups A to D. Within the European sequence types, Img.Vi100 and Img.4262 grouped together with a bootstrap confidence value of 72 , and similarly Img. 8 and Img.28 grouped together with a bootstrap of 75. All other European mid-G sequences formed independent branches leading directly back to the inferred ancestral node of the $M$ genogroup. Among the North American reference strains resequenced for this work, the mid-G sequences of isolates RB1, IHNFryer and IHNcod fell into the U genogroup, WRAC was in the $M$ genogroup, and SRCV was in the L genogroup, as expected.

\section{Analysis of European strains in context of further $M$ genogroup virus isolates from Columbia River Basin}

It is well known that phylogenetic trees can sometimes be strongly affected by the exact set of sequences used in the analyses. Therefore, to test the validity of our results we analysed the European sequences further with 37 North American IHNV midG sequences selected to represent the range of IHNV genetic types observed to date in North America (Kurath et al. in press). Relative to the data set described earlier, this representative data set included more sequence types from the Columbia River Basin, in which essentially all of $\mathrm{M}$ genogroup viruses occurring in North America are found (Garver et al. 2003, Kurath et al. 2003). In particular, this data set included representatives of all 6 subgroups in the M genogroup as defined in extensive studies of IHNV in the Columbia River basin (Garver et al. 2003, Troyer \& Kurath 2003). It was of particular interest to test whether it would be feasible to find a possible ancestor virus for the European group. The phylogenetic results obtained again confirmed that the European strains belong to the $\mathrm{M}$ genogroup, but are not within any of the subgroups (A to F) previously defined, for this extended data set (Fig. 2). In this tree, the European sequence types Img. 8 and Img.28 grouped together with a marginally significant bootstrap value of 72 , but otherwise all European types fell on individual branches linked directly to the ancestral node of the M genogroup. Thus, no specific ancestor for the European IHNV was identified.

\section{Full G gene}

Since it was not possible to identify the ancestry of the European strains using the mid-G region, the full-length $G$ gene ORF sequence was used to test the phylogeny. Newly determined G ORF sequence types were given the prefix 'Ig' for IHNV G. Among the 10 European IHNV isolates, Virus Strains IE.42 and IE.62 were identical in G ORF sequence, comprising sequence type Ig.4262, but they differed in NV ORF sequences (see next subsection). All other European isolates had unique G ORF sequences that were not identical to any sequences of North American isolates. Only a small number of full sequences of the G gene from North American IHNV strains are available for comparison (Nichol et al. 1995). For this analysis we used complete G ORF sequences of 11 strains from Nichol et al. (1995) and our own sequences from North American isolates SRCV, RB, IHNFryer and IHNcod.

The resulting tree is shown in Fig. 3. This analysis demonstrated that the European strains are monophyletic, with a bootstrap value of $90 \%$. By the fulllength $\mathrm{G}$ gene ORF sequences the European cluster is again most closely grouped with North American isolates in the M genogroup, with a bootstrap value of 85 . Within this European cluster, 2 subgroups can be associated with a likely origin in France and Italy. These subgroups are represented by Strain IE.Vi100, isolated from rainbow trout imported from France, and Strain IE.332, the first German outbreak, isolated from rainbow trout from Italy. The existence of these branches was supported by bootstrap values of 91 and $84 \%$, respectively.

\section{NV gene}

Full length NV gene ORF sequences from the same set of isolates shown in Fig. 3 were analysed to generate the NV phylogenetic tree in Fig. 4, in 


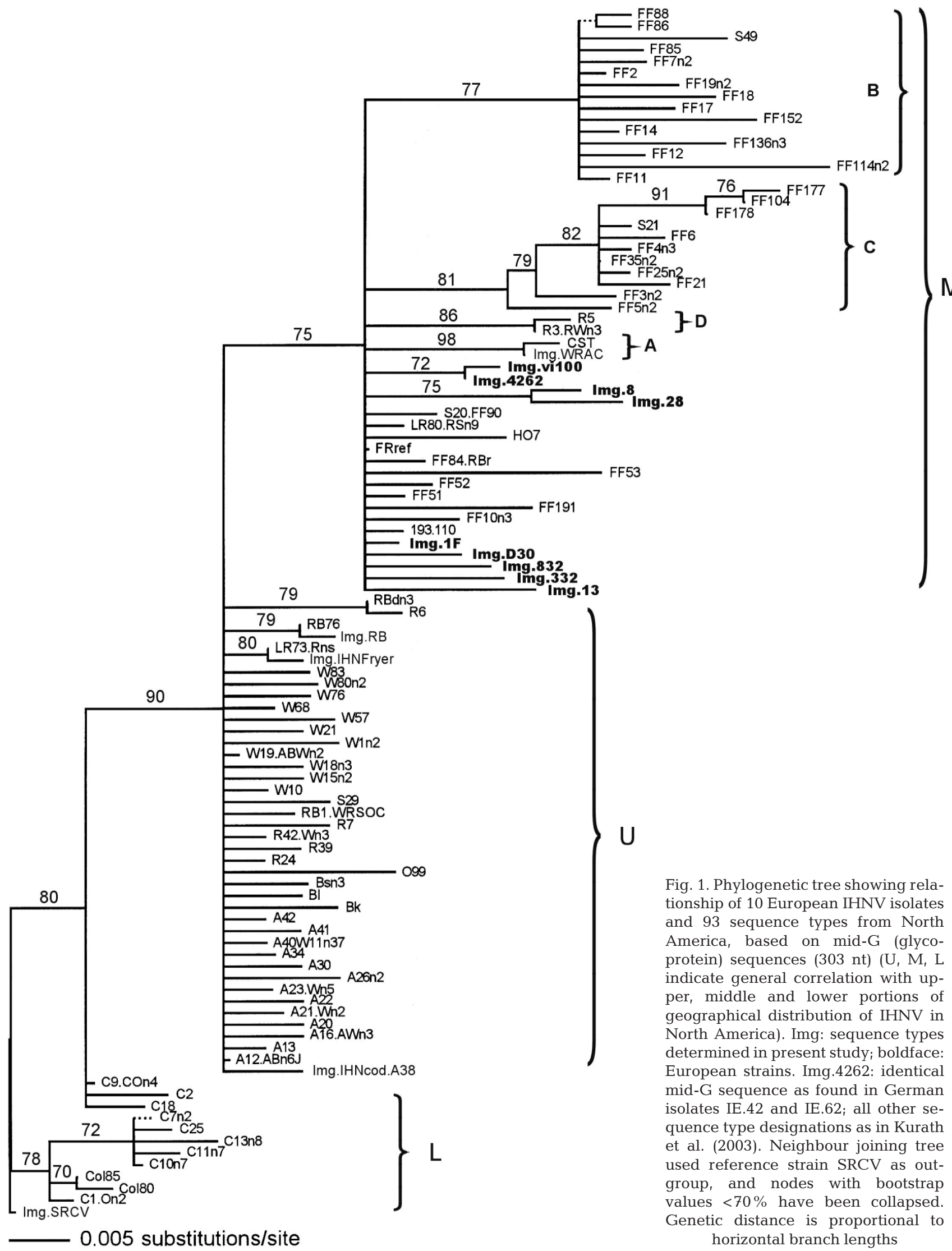




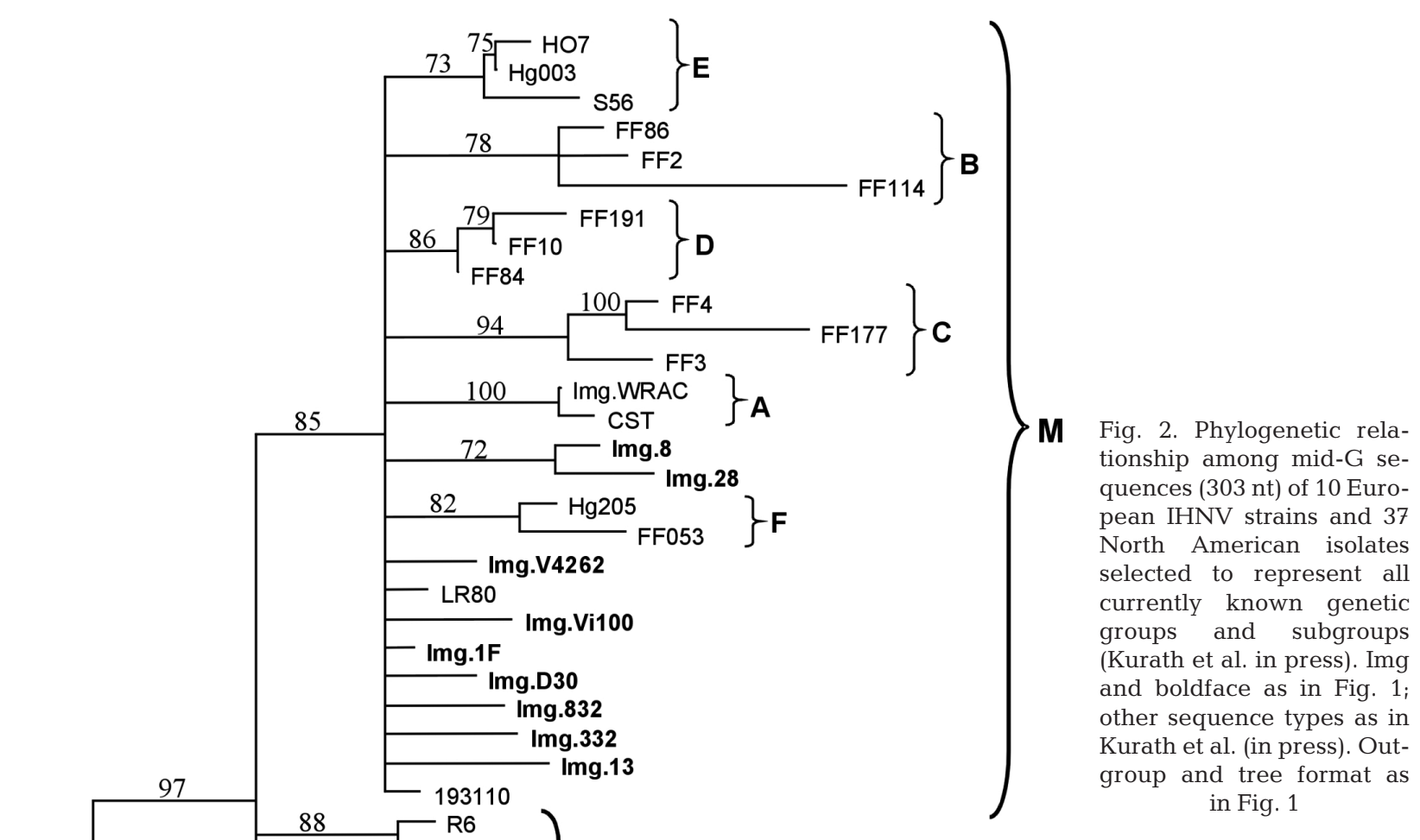

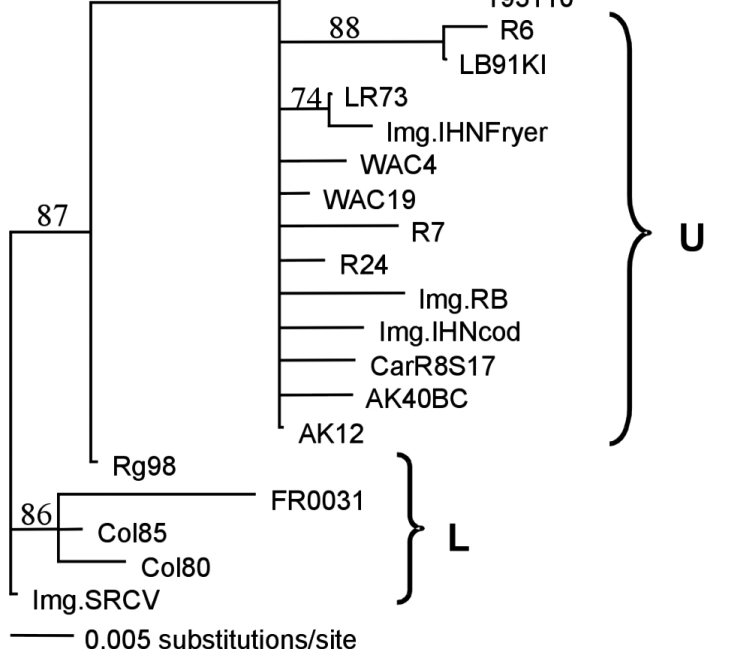

which sequence types bear the prefix 'Inv', for IHNV NV. The European isolates were again monophyletic, with a bootstrap value of 74 . However, with the NV gene sequences, the $\mathrm{U}, \mathrm{M}$ and $\mathrm{L}$ genogroups were not clearly resolved, so the closest ancestral genogroup could not be discerned. The discordant position of the North American Col85 NV sequence outside the established L genogroup was also evident in both neighbour joining and parsimony analyses of the NV ORF sequences of the 12 North American isolates described previously (Nichol et al. 1995) (data not shown), demonstrating that this grouping is not due to inclusion of the European isolates in this analysis. quences (303 nt) of 10 European IHNV strains and 37 North American isolates selected to represent all currently known genetic groups and subgroups (Kurath et al. in press). Img and boldface as in Fig. 1; other sequence types as in (in press). Outin Fig. 1

\section{DISCUSSION}

This study was based predominantly on virus isolated from the years 1987 to 2002 and represents the development of the IHNV situation in Europe during this time span. Our molecular analyses represent the natural course of IHNV infections and evolution over the $\sim 15$ yr since the first detection of this pathogen in Europe. To investigate the molecular epidemiological linkage, we analysed the nucleotide sequences of the $\mathrm{G}$ and NV genes of a series of IHNV isolates, mostly from Germany. The G and NV genes were amplified by RT-PCR, and products were directly sequenced; thus the data represent the master sequence for each isolate.

Presently, extensive sequence comparison of IHNV strains in North America suggests that this virus species can be subdivided phylogenetically into 3 genogroups, U, M and L (Kurath et al. 2003). Our results on the monophyletic groupings of European isolate sequences in the full length G and NV gene analyses indicate the likelihood that IHNV was introduced to Europe only once. Future analyses of full length gene sequences from a larger number of virus isolates from Europe and North America, and also from Japan, Southeast Asia and Russia, would be useful in confirming this hypothesis. The full length $G$ gene analysis indicated that the European isolate sequences were most closely related to the $\mathrm{M}$ genogroup, but as the full 


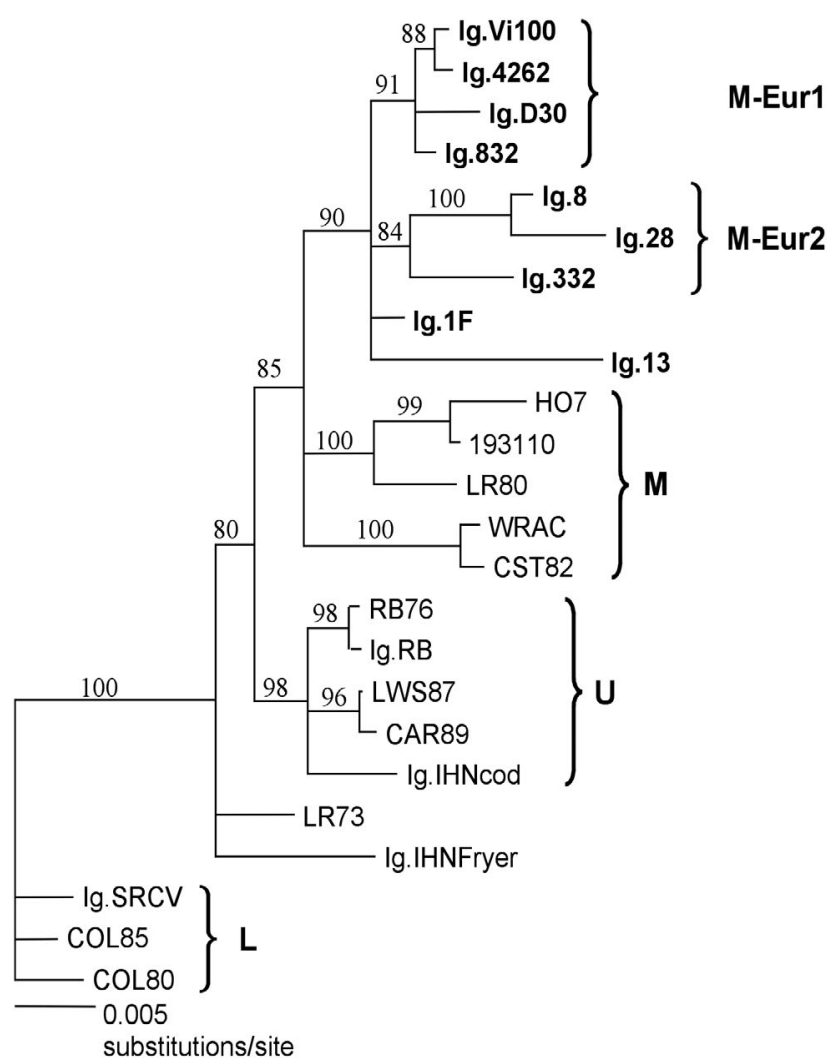

Fig. 3. Phylogenetic tree showing relationship of 10 European IHNV strains and 15 North American reference strains from U, M and L genogroups, based on analysis of full-length G gene open reading frame, ORF (1527 nt). Ig: sequence types determined in present study; boldface: European strains; other sequence types as in Nichol et al. (1995). Outgroup and tree format as in Fig. 1

length NV gene tree did not resolve the 3 genogroups, no relationship could be discerned. Analyses of the European isolates using the variable 'mid-G' sequence region was first done using the 93 mid-G sequence types identified in a broad study of IHNV throughout North America (Kurath et al. 2003). We also analysed the European mid-G sequences with a different data set that contained more representatives from the Columbia River basin in North America. This large watershed is of particular interest because essentially all M genogroup IHNV in North America occur there (Garver et al. 2003), and within the basin there is an IHNV endemic focus in the rainbow trout aquaculture region known as the Hagerman Valley in Idaho (Troyer et al. 2000, Troyer \& Kurath 2003). Both mid-G sequence analyses confirmed the placement of the European IHNV sequences within the M genogroup. However, with this short sequence region the European isolate sequences did not appear monophyletic, and no direct ancestor of the European IHNV was identified. Specifically, no link was identified between the European isolate sequences and any of the known M subgroups hypothesised to have evolved relatively recently (over approximately the last $20 \mathrm{yr}$ ) in the IHNV endemic Hagerman Valley. Instead, from our analyses we can only conclude that the IHNV in Europe appears to have been derived from an original M genogroup ancestor. The source of this inferred M genogroup ancestor has not been identified, but the well documented history of IHNV in North America pre-dates its discovery in Europe by over $30 \mathrm{yr}$ (Wolf 1988, Bootland \& Leong 1999), making it most likely that European IHNV originated, either directly or indirectly, from a North American source. The frequent transport of trout eggs and fry from North America to Europe (Bootland \& Leong 1999) provides a logical

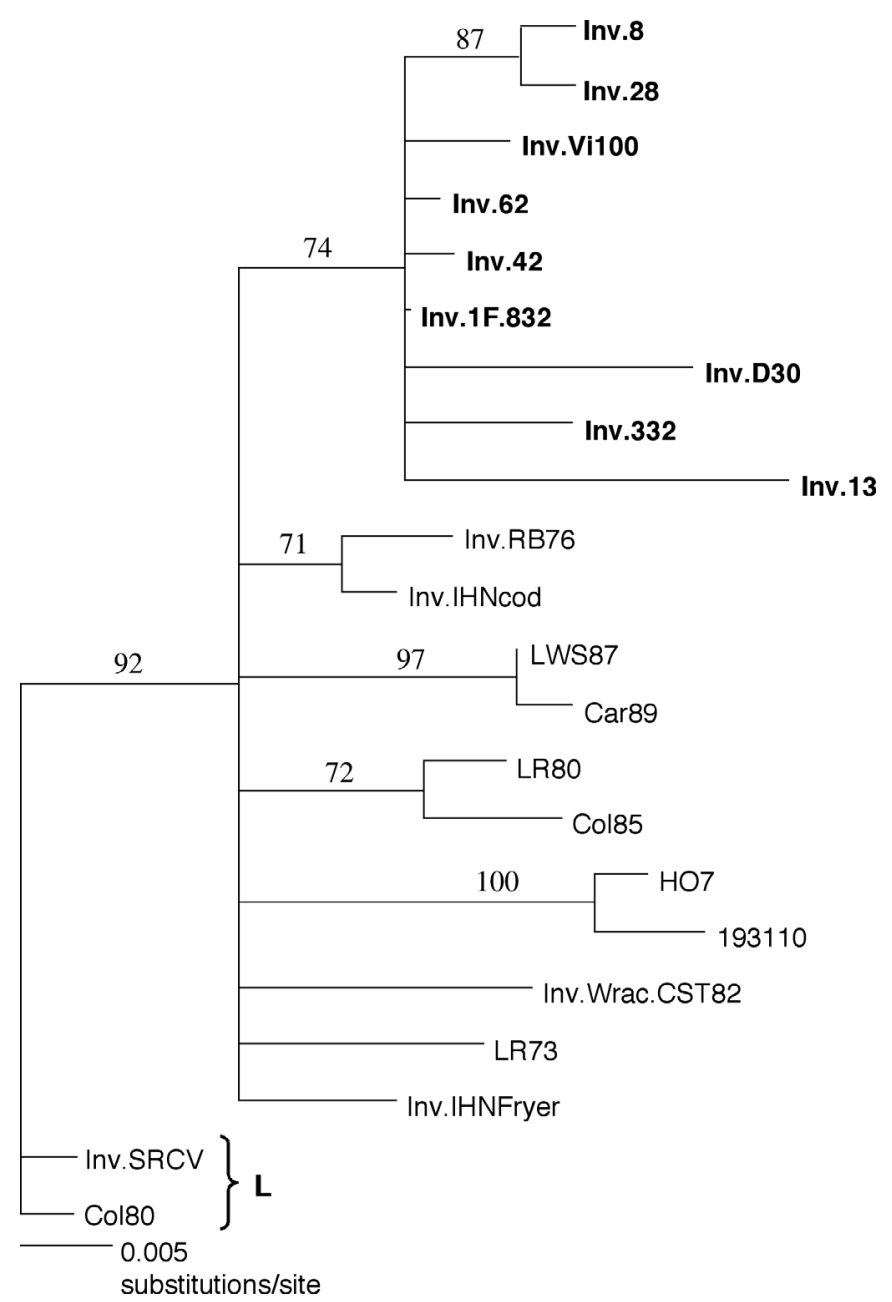

Fig. 4. Phylogenetic tree showing relationship of 10 European IHNV strains and 15 North American reference strains from $\mathrm{U}, \mathrm{M}$ and L genogroups, based on analysis of NV gene ORF (336 nt). Inv: sequence types determined in present study; boldface: European strains; other sequence types as in Nichol et al. (1995). Neighbour joining tree used reference strain SRCV as outgroup. Tree format as in Fig. 1 
mechanism for such introduction, but it is also possible that the route of IHNV into Europe may have been indirect, through a source such as Japan or Asia, where it is thought IHNV was introduced from North America in the late 1960s (Sano et al. 1977).

It was our a further aim to demonstrate the development of this virus during its spread within Europe. The mid-G and NV analyses were relatively uninformative about relationships within the European isolates, possibly because of the short lengths of these sequences and the high similarity between all IHNV in Europe. However, the phylogenetic tree of the complete G gene ORFs from outbreaks between 1987 and 2002 increased our understanding of their molecular epidemiology. It is interesting that 2 subgroups could be distinguished within the European isolates (Fig. 3). Of these, 1 group, M-Eur1 (Ig.Vi100, Ig.4262, Ig.D30 and Ig.832), contained virus isolates which seem to have originated from European viruses in France: Strain Vi100 was most likely introduced from France to Germany in 1996 with infected rainbow trout; Strains IE.42, IE.62 and IE.D30 were circulating in the Black Forest not far away from the border to France in 1995; Isolate IE.832 was isolated in the southern part of Germany, with no obvious link to introduction from France. The second subgroup, M-Eur2 (Ig.8, Ig.28 and Ig.332), may represent the Italian type of IHN virus, as Strain IE.332 was the first IHNV isolated in Germany after fish were introduced from Italy in 1992.

The finding of these 2 defined subgroups within the European isolates would be consistent with an hypothesis that IHNV evolved in France and Italy independently, after its first introduction to Europe (sometime prior to 1987) and before its introduction(s) to Germany. There is an intensive trade with rainbow trout between Italy and Germany as well as between France and Germany. On the other hand, virus already established in Germany circulated in different regions and may have diverged during replication within Germany.

Within the monophyletic cluster of European IHNV isolates in the G ORF tree there were 2 isolates that did not fall into either of the 2 subgroups described above. The isolate IE.13 from elver was different from all other isolates but, nevertheless, fitted well within the European group. The only other sequence that did not fall into one of the 2 subgroups was Isolate IE.1F, which was the first IHNV isolated in France in 1987, much earlier than any of the other European isolates. This supports the isolated development of IHNV in European countries after its initial introduction. It should be pointed out that the 2 subgroups were supported by high bootstrap values.

This pattern is consistent with introductions and spread within defined regions. It may be that other genetic lineages of IHNV were also present and also caused outbreaks. However, we did not find any additional viral lineages despite sequencing typical virus isolates from other regions in Germany. We have recently sequenced 3 additional isolates from different regions and have found that their G ORF sequences are identical to those of Isolates IE.28, IE.Vi100 and IE.332. The geographical situation of Germany complicates epizootiological analysis: there is much transport of live fishes between Germany, Denmark, France and Italy, and with this, the danger of continuous spreading of infection. The evolution of 2 different subgroups of IHNV in Europe must have occurred early after introduction of the virus to Europe, but the geographical distribution of the subgroups is no longer distinct.

With regard to other phenotypic features, it is interesting that Virus Isolate IE.8, isolated in Germany in 1999 (Fichtner et al. 2000) differs in reactivity with diagnostic monoclonal antibodies, but does not appear unusual in genetic analyses. Indeed, all European IHNV isolates described here are genetically markedly homogeneous. They are all within the M genogroup, and most likely originated either from a single introduction event, or from a small number of introductions from the same $\mathrm{M}$ genogroup source in North America sometime prior to 1987. In future studies using additional IHNV isolates from a wider range of countries in Europe it will be interesting to see if they are all within the $\mathrm{M}$ genogroup, and if the apparently monophyletic nature of European IHNV can be confirmed.

Acknowledgements. We thank K. A. Garver for assistance with the computer analyses, and I. Fabian and A. Braun for excellent technical assistance.

\section{LITERATURE CITED}

Baudin-Laurencin F (1987) IHN in France. Bull. Eur Assoc Fish Pathol 7:104

Bergmann SM, Fichtner D, Skall HF, Schlotfeldt HJ, Olesen NJ (2003) Age- and weight-dependent susceptibility of rainbow trout Oncorhynchus mykiss to isolates of infectious hematopoietic necrosis virus (IHNV) of varying virulence. Dis Aquat Org 55:205-210

Bootland LM, Leong JC (1999). Infectious hematopoietic necrosis virus. In: Woo PTK, Bruno DW (eds) Fish diseases and disorders, Vol. 3. CAB International, Wallingford, Oxon, p 57-112

Bovo G, Giorgetti G, Jørgensen PEV, Olesen NJ (1987) Infectious hematopoietic necrosis: First detection in Italy. Bull Eur Ass Fish Pathol 7:124

Enzmann PJ, Dangschat H, Feneis B, Schmitt D, Wizigmann G, Schlotfeldt HJ (1992) Demonstration of IHN virus in Germany. Bull Eur Ass Fish Pathol 12:185-188

Enzmann PJ (2000) Molecular biology of fishpathogenic rhabdoviruses. In: Fingerman $M$, Nagabhushanam R (eds) Recent advances in marine biotechnology, Vol. 5. Immunobiology and pathobiology. Science Publishers, Plymouth, p 269-293 
Fichtner D, Bergmann S, Enzmann PJ, Granzow H, Schütze H, Mock D, Schäfer JW (2000) Isolation and characterisation of a variant strain of infectious hematopoietic necrosis (IHN) virus. Bull Eur Ass Fish Pathol 20: 135-142

Fryer JL, Rohovec JS, Tebbit GL, McMichael JS, Pilcher KS (1976) Vaccination for control of infectious diseases in Pacific salmon. Fish Pathol 10:155-164

Garver KA, Troyer RM, Kurath G (2003) Two distinct phylogenetic clades of infectious hematopoietic necrosis virus overlap within the Columbia River basin. Dis Aquat Org 55:187-203

Koener JF, Passavant CW, Kurath G, Leong J (1987) Nucleotide sequence of a cDNA clone carrying the glycoprotein gene of infectious hematopoietic necrosis virus, a fish rhabdovirus. J Virol 61:1342-1349

Kurath G, Garver K, Troyer RM, Emmenegger EJ, EinerJensen K, Anderson ED (2003) Phylogeography of infectious hematopoietic necrosis virus in North America. J Gen Virol 84:803-814

Kurath G, Garver KA, Batts WN, Emmenegger EJ (in press) Genetic typing of infectious hematopoietic necrosis virus. Annu Rev Fish Dis

Miller TA, Rapp J, Wastlhuber U, Hoffmann RW, Enzmann PJ (1998) Rapid and sensitive reverse transcriptase-polymerase chain reaction based detection and differential diagnosis of fish pathogenic rhabdoviruses in organ samples and cultured cells. Dis Aquat Org 34:13-20

Morzunov SP, Winton JR, Nichol ST (1995) The complete

Editorial responsibility: Jo-Ann Leong,

Kaneohe, Hawaii, USA genome structure and phylogenetic relationship of infectious hematopoietic necrosis virus. Virus Res 38:175-192

Nichol ST, Rowe JE, Winton JR (1995) Molecular epizootiology and evolution of the glycoprotein and non-virion protein genes of infectious hematopoietic necrosis virus, a fish rhabdovirus. Vir Res 38:159-173

Pringle CR (1999) Virus taxonomy - 1999. The universal system of virus taxonomy, updated to include the new proposals ratified by the International Committee on Taxonomy of Viruses during 1998. Arch Virol 144:421-429

Sano T, Nishimura T, Okamoto N, Yamazaki T, Hanada $H$, Watanabe Y (1977). Studies on viral diseases of Japanese fish. VI. Infectious hematopoietic necrosis (IHN) of salmonids in the mainland of Japan. J Tokyo Univ Fish 63:81-85

Schütze H, Enzmann PJ, Kuchling R, Mundt E, Niemann H, Mettenleiter TC (1995) Complete genomic sequence of the fish rhabdovirus infectious hematopoietic necrosis virus. J Gen Virol 76:2519-2527

Troyer RM, Kurath G (2003) Molecular epidemiology of infectious hematopoietic necrosis virus reveals complex virus traffic and evolution within southern Idaho aquaculture. Dis Aquat Org 55:175-85

Troyer RM, LaPatra SE, Kurath G (2000) Genetic analyses reveal unusually high diversity of infectious hematopoietic necrosis virus in rainbow trout aquaculture. J Gen Virol 81:2823-2832

Wolf K (1988) Fish viruses and fish viral diseases. Cornell University Press, Ithaca, NY

Submitted: November 20, 2004; Accepted: April 5, 2005

Proofs received from author(s): September 13, 2005 